\title{
A 17-year-old female patient with sigmoid volvulus: Considering the diagnosis
}

\author{
On yedi yaşındaki kız hastada sigmoid volvulus: Tanıyı düşünmek
}

Mustafa Uğur ${ }^{1}$, Akın Aydoğan ${ }^{1}$, Seçkin Akküçük ${ }^{1}$, Ramazan Davran², Aydın Kaplan ${ }^{1}$

\begin{abstract}
Sigmoid volvulus is an extremely rare disease among young adults. This may cause delay in diagnosis and treatment and so it may cause life threatening ischemia and necrosis at the colon. In this article we present the case which was confirmed to be sigmoid volvulus with tomographic examinations which was carried upon suspicion of sigmoid volvulus in a 17 years old girl who attended with increasing abdominal pain, constipation, obstipation and distention complaints. Taking a detailed history, performing a physical examination and evaluation of laboratory tests of a patient presenting with complaints like abdominal pain, constipation and distention are the most essential steps to diagnose the sigmoid volvulus. The most important method for early diagnosis in young adults is to keep the diagnosis in mind. So it would be possible to plan advanced radiologic and endoscopic examinations which would confirm the diagnosis. J Clin Exp Invest 2014; 5 (1): 121-124
\end{abstract}

Key words: Sigmoid volvulus, detorsion, young patient

\section{INTRODUCTION}

Sigmoid volvulus is a disease originating from rotation of the colon around its own mesentery [1]. It is classically known as the disease of 7th and 8th decade. It is seen extremely rarely in kids and young adults [2,3]. As sigmoid volvulus is not considered in young patients with abdominal pain, constipation and obstipation; advanced radiologic and endoscopic examinations needed for the diagnosis are not performed. As a result early diagnosis and treatment of children and young patients are delayed. However early treatment of this disease which sometimes begins acutely and sometimes insidiously; is the most efficient method for preventing life threatening ischemic and necrotic complications [4].

\section{CASE}

Seventeen years old female patient attending the emergency care unit with abdominal pain, nausea-

\section{ÖZET}

Sigmoid volvulus genç erişkinlerde oldukça nadir görülen bir hastalıktır. Bu durum tanı ve tedavi girişimlerinde gecikmeye neden olarak kolonda hayatı tehdit eden iskemi ve nekroz gelişmesine yol açabilir. Bu yazıda giderek artan karın ağrısı, konstipasyon, obstipasyon ve distansiyon şikayetleriyle acil servise başvuran 17 yaşındaki genç kız hastada sigmoid volvulus tanısından şüphelenilerek yapılan tomografik incelemede tanısı doğrulanan olguyu sunduk. Tanıdaki en önemli adım karın ağrısı, konstipasyon, distansiyon gibi şikayetlerle başvuran hastalarda ayrıntılı bir öykü, fizik muayene ve uygun laboratuar testlerinin incelenmesi ile hekimin tanıdan şüphelenmesidir. Genç hastalarda erken tanıya götürecek en önemli yol öncelikle tanının akılda bulundurulmasıdır. Böylece tanıyı doğrulayacak ileri radyolojik ve endoskopik incelemelerin zaman kaybedilmeden planlanması mümkün olacaktır.

Anahtar kelimeler: Sigmoid volvulus, detorsiyon, genç hasta

vomiting, distention and constipation; states that abdominal pain started 4 days ago as a mild pain and during the last day it was accompanied with nausea and vomiting and the pain has increased. Physical examination revealed that her abdomen was moderately distended and with auscultation intestinal sounds were found to be hypoactive and occasionally metallic sounds were heard. In abdomen there was severe tenderness at all quadrants and especially both lower quadrants showed defense. Rectal examination revealed that rectum was empty and there was no pathology. White Blood Cell (WBC) and biochemical values were in normal limits.

Abdominal X-ray revealed extremely dilated colon segments. Gas shadows were not seen in distal colon and rectum (Figure 1). Abdominopelvic Computerized Tomography (CT) was performed upon suspicion of sigmoid volvulus. Results of abdominopelvic CT showed dilatation areas up to $12 \mathrm{~cm}$ in

\footnotetext{
${ }^{1}$ Mustafa Kemal üniversitesi Tıp Fakültesi Genel Cerrahi Anabilim Dalı, Hatay, Türkiye

${ }^{2}$ Mustafa Kemal üniversitesi Tıp Fakültesi Radyoloji Anabilim Dalı, Hatay, Türkiye
}

Correspondence: Mustafa Uğur,

Mustafa Kemal üniversitesi Tıp Fakültesi Genel Cerrahi Anabilim Dalı, Hatay Email: drmustafaugur@gmail.com 
diameter at descending, ascending and transverse colons; and torsion at the sigmoid colon (Figure 2A and $2 \mathrm{~B}$ ). For treatment, intravenous fluid treatment was initiated and emergency colonoscopy was performed. Colonoscopy did not reveal any finding of ischemia or necrosis. However, the affected colon segment could not be detorsioned. Upon this the patient underwent emergency operation to prevent complications.

On the patient who underwent laparotomy it was seen that sigmoid colon rotated 2 times around its mesentery and the effected segment showed dilatation and edema. There was not any ischemia and necrosis (Figure 3). Sigmoid colon was detorsioned and upon finding, it was longer than normal, resection of sigmoid colon and end colostomy (Hartmann Procedure) operations were performed. Patient, who did not develop any complications on post-operative follow-ups, was discharged on $5^{\text {th }}$ day.

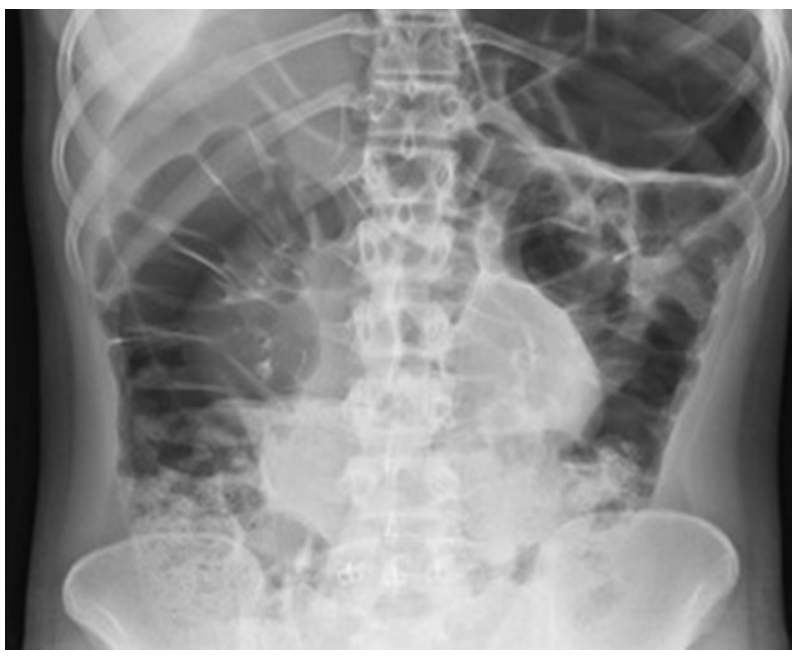

Figure 1. Dilated Colon Segments on Abdominal X-ray

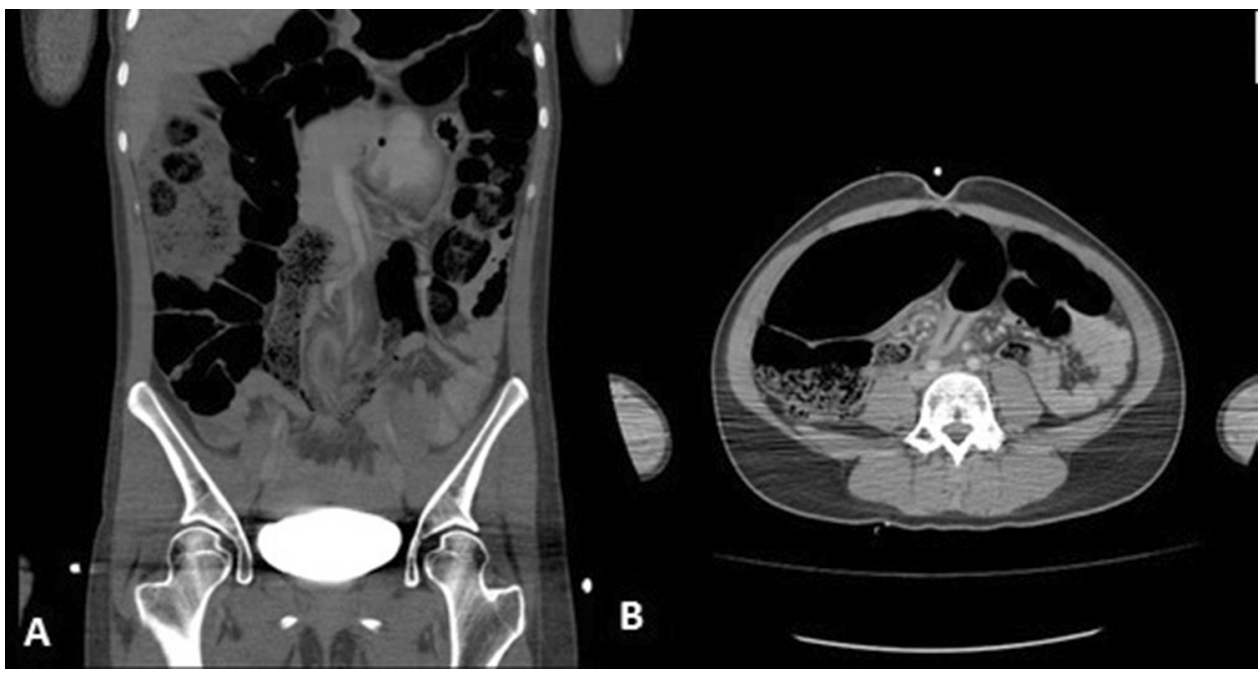

Figure 2. A. Sigmoid Volvulus Observed on Axial Cross-Section with CT B. Sigmoid Volvulus Observed on Transverse CrossSection with CT

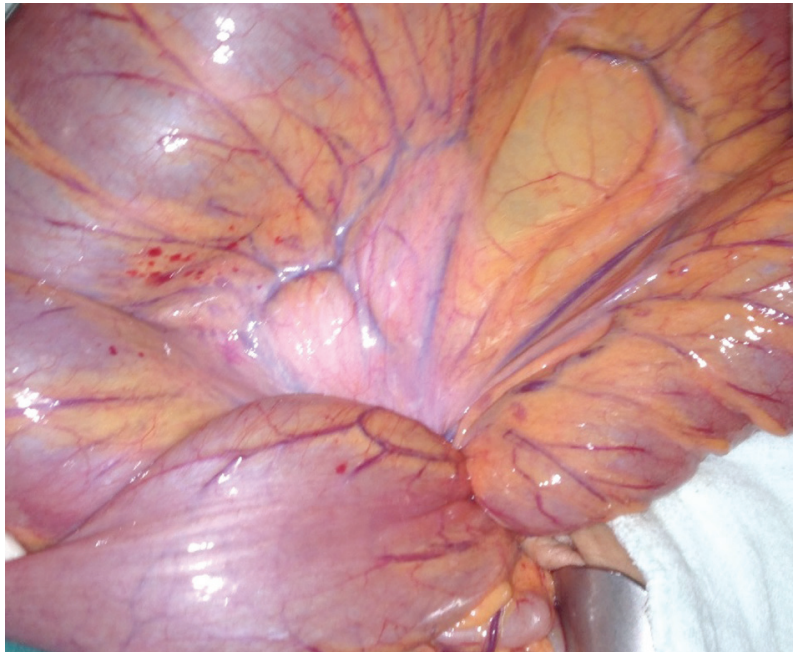

Figure 3. Intraoperative view of sigmoid colon

\section{DISCUSSION}

Sigmoid volvulus is a disease originating from rotation of sigmoid colon around its own mesentery [1]. The disease shows a variable geographic distribution. While it is seen with young and healthy patients of 40-50 ages at the region along developing countries, it is more common among patients of $60-80$ years of age with coexisting problems at developed countries. It is extremely rare in children and adolescents [2,3]. While chronic constipation is blamed at developed countries; diet containing high amount of fibers is thought to be etiology at undeveloped countries [1]. Other etiologic factors include, anatomic variations, neurologic diseases and megacolon [4]. In our case the patient did not have any previously known disease, however dur- 
ing the operation sigmoid colon was found to be longer than normal and mobile.

The disease has a sudden onset acute form originating from obstruction of bowels and an insidious subacute form originating from partial obstruction [1]. Abdominal examination may show variable signs from mild localized tenderness to diffuse peritonitis. Rectal examination can be totally normal or may show bright red blood or melena [5]. Patients with sigmoid volvulus usually attend with constipation, increasing abdominal distention and severe abdominal pain [6]. In our case complaints like abdominal pain, constipation and distention were found to be started as mild symptoms 4 days before attending the hospital and became more severe on the day she attended the emergency unit. Patient's unwillingness for attending the hospital for mild symptoms may cause development of complications by delaying diagnosis and treatment.

The most important step towards diagnosis is the suspicion of the physician upon taking a detailed history, performing a physical examination and evaluation of laboratory tests of a patient presenting with complaints like abdominal pain, constipation and distention.

Laboratory examination may reveal leukocytosis, electrolyte disturbances and metabolic acidosis [5]. In our case WBC count and biochemical values were normal. Laboratory values within normal ranges should not stop the physician from further questioning the patient.

Seeing coffee bean or omega sign (inverted $U$ sigmoid) on plain abdominal radiography has a sensitivity of $35 \%$ to $60 \%$. In case of perforation subdiaphragmatic free air could be seen. CT provides a more accurate and reliable diagnosis (CT Whirl sign). It is an imaging modality with $100 \%$ accuracy especially during early stages of the disease [6]. In the abdominal X-ray of our patient, dilated bowel loops were seen. There was not any gas in the rectum. At this stage the patient was thought to be sigmoid volvulus so abdominopelvic $C T$ was performed. The results of tomographic evaluation showed the accuracy of our decision. Tomography showed the torsion of sigmoid colon clearly alongside with dilated colon segments.

Colonoscopic examination should be planned for diagnosis and treatment of patients suspected to have sigmoid volvulus without signs of peritonitis. With colonoscopy it is also probable to detect possible ischemia and necrosis of colonic mucosa. The obstruction should be tried to be removed by fixing the torsioned colon segments by performing colonoscopy or colonoscopy and laparotomy together. These procedures have a high success rate $(87 \%)$. The most important disadvantage is high recurrence rate $(40-70 \%)$. For this reason following a successful endoscopic detorsion operation, an surgical treatment method like resection-anastomosis, colopexy or mesocoloplasty should be performed more securely under elective conditions (mortality $6.6 \%)[1,6]$. We performed colonoscopy for treatment, following the diagnosis of sigmoid volvulus via tomographic examination. But could not perform detorsion despite all our efforts. In the meantime we did not find laparostomy appropriate as the patient's distention has increase thoroughly.

While treating intestinal volvulus the aim should be removing the obstruction and preventing recurrence [6]. When a patient is considered having sigmoid volvulus first thing should be fluid and electrolyte resuscitation and starting wide spectrum antibiotics especially when the patient is suspected to have ischemic bowel segments.

When colonoscopy or simultaneous colonoscopy and laparascopy interventions fail, one choice among surgical sigmoidopexy, sigmoid resection and end colostomy (Hartmann procedure) or sigmoid resection and primary anastomosis should be performed [1]. Because of advanced intestinal edema, undone bowel cleansing and advanced mismatch between the diameters of bowel ends; we found appropriate to perform sigmoid resection and end colostomy which is to be closed at a later date.

In case of presence of peritonitis signs, emergency surgery is required. Emergency surgical interventions have a high mortality rate $(43.5 \%)$. It is advised to perform resection and to open colostomy in case of ischemia and necrosis $[1,6]$.

In conclusion, we think that the most important step towards the diagnosis of sigmoid volvulus, especially with young patients, is to consider the diagnosis. Naturally, investigations like CT or colonoscopy which would provide the definitive diagnosis will not be performed when sigmoid volvulus is not considered in young patients with abdominal pain and signs of bowel obstruction especially if the laboratory results are normal and radiographic examination does not reveal any characteristic findings of sigmoid volvulus. To avoid this, it should be kept in mind that sigmoid volvulus could develop with young patients and investigations should be continued until the diagnosis of sigmoid volvulus is excluded in a patient with signs of bowel obstruction. 


\section{REFERENCES}

1. Weingrow D, McCague A, Shah R, Lalezarzadeh F. Delayed presentation of sigmoid volvulus in a young woman. West J Emerg Med 2012;13:100-102.

2. McCalla TH, Arensman RM, Falterman KW. Sigmoid volvulus in children. Am Surg 1985;51:514-519.

3. Onder A, Kapan M, Arikanoglu Z, et al. Sigmoid colon torsion: mortality and relevant risk factors. Eur Rev Med Pharmacol Sci 2013;17:127-132.
4. Salinas NL, Carr SR, Han D, Mahmoud NN. A surprising twist to an old problem: sigmoid volvulus in a 19-year-old man. Am Surg 2007;73:284-286.

5. Rabinovici R, Simansky DA, Kaplan O, et al. Cecal volvulus. Dis Colon Rectum 1990;33:765-769.

6. Chang CJ, Hsieh TH, Tsai KC, Fan CM. Sigmoid Volvulus in a Young Woman Nearly Misdiagnosed As Fecal Impaction. J Emerg Med 2013;44:611-613. 